\title{
Poznańska Śródka - granice fizyczne i mentalne w mieście
}

\author{
Teresa Bardzińska-Bonenberg \\ Wydziat Architektury i Wzornictwa, Uniwersytet Artystyczny w Poznaniu, \\ e-mail:teresa@bardzinska-bonenberg.pl
}

Streszczenie: Śródka istniała zanim powstał lokacyjny Poznań. Położenie nad rzeką i główna droga ze wschodu na zachód a także do Gdańska ustabilizowały jej kupiecki, potem produkcyjny charakter. Kolejne powodzie, skutek budowy pruskiej twierdzy obniżyły atrakcyjność dzielnicy zamieszkiwanej przez polską ludność. Dwudziestolecie międzywojenne niewiele zmieniło sytuację. Działania II wojny światowej, likwidacja mostu, linii tramwajowej, nowa dwupasmówka, która zajęła teren śródeckiego rynku spowodowały, że dzielnica została odgrodzona od miasta. W 2006 roku Śródka została objęta Miejskim Programem Rewitalizacji. Natychmiastowe podniesienie czynszów spowodowało zamknięcie większości sklepów i nielicznych lokali oraz wyprowadzenie się najlepiej rokujących mieszkańców. Stopniowo program zaczął działać: Trakt Królewsko-Cesarski sprowadził turystów podobnie jak muzeum Brama Poznania, mural odwołujący się do historii i klimatu dawnej Sródki, zmieniły obraz dzielnicy. Pojawiły się lokale gastronomiczne, sklepy i hotel. Za sprawą Rady Osiedla dokonuje się integracja mieszkańców i przyzwyczajanie Poznaniaków do „nowej” interesującej, historycznej dzielnicy miasta. Celem referatu jest pokazanie historii deterioracji dzielnicy i efekty działań lokalnej społeczności reprezentowanej przez Radę Osiedla. Jej wpływ na decyzje administracji miasta zahamował proces degradacji dzielnicy i zapoczątkował proces integracji mieszkańców. Istnienie grupy nacisku wnoszącej racjonalne koncepcje i doprowadzającej do ich realizacji, w połączeniu z programami unijnymi, pozwolił na stopniowy powrót Śródki do Poznania zarówno w sferze materii jak i ducha.

Słowa kluczowe: Śródka, decyzje, rozwój, degradacja, sprzeczność, społeczność, administracja.

\section{Wprowadzenie}

Miasto, a zwłaszcza miasto współczesne nie jest jednolitą strukturą. Jego stopniowy rozwój spowodował powstawanie zespołów o odrębnej jakości: różnym układzie przestrzennym, skali, estetyce. Niektóre fragmenty miast zajmują tereny wydzielone: może to wynikać z warunków naturalnych (topografia), może być antropogeniczne (trasy szybkiego ruchu) ale może mieć również charakter emocjonalny, zakodowany w świadomości mieszkańców. Od dwudziestego wieku, w odróżnieniu od minionych okresów historycznych, miasto jest kształtowane w oparciu o wiedzę i relatywnie duże możliwości techniczne, które pozwalają na istotne ingerencje tworzące podziały w mieście lub niwelujące je.

Przykładem może być splot decyzji, które od XIII w. kształtowały poznańską Śródkę, wyznaczając jej kolejno rolę ważnej, potem bogatej, następnie niebezpiecznej i w końcu (chyba już) modnej dzielnicy.

Praca analizuje przyczyny techniczne, polityczne i społeczne zjawiska w oparciu o literaturę, ikonografię i relacje ludzi. 


\section{Czas rozwoju}

Śródka istniała zanim powstał lokacyjny Poznań, lokacja prawdopodobnie nastąpiła przed 1245 rokiem, środowe targi nadały jej nazwę, a przeprawa przez Cybinę i Wartę zapewniła dalszy rozwój, również po wybudowaniu pierwszych mostów przez rzeki. W trakcie prac prowadzonych w korycie Cybiny kilka lat temu odkryto pale średniowiecznego mostu łączącego Ostrówek z Ostrowem Tumskim.

W najwcześniejszych czasach dzisiejszą dzielnicę stanowiły dwie osady: Ostrówek i Śródka. Niegdyś znajdowały się one na dwóch sąsiadujących wyspach. Ostrówek, od którego nazwę wzięła główna ulica obecnej Śródki był położony bezpośrednio przy korycie Cybiny i kiedy w XV wieku otrzymał lokację, był najmniejszym polskim miastem [1]. Wkrótce jednak został wchłonięty przez rozrastającą się Śródkę. Targi odbywały się na nieistniejącym obecnie śródeckim Rynku. Na północ od niego położony był parafialny kościół Św. Małgorzaty, wzmiankowany już w XIII w., kiedy był prawdopodobnie drewniany. Obecna, późnogotycka budowla datowana jest na XV-XVI w., kaplice i ogradzający mur z ozdobnymi bramami są późniejsze. Teren wokół kościoła zajmował parafialny cmentarz, który zniknął już w XX w. [2]. Przykościelny plac od lat 60. XX wieku pełni funkcję Rynku. Jego północno zachodni narożnik tworzy dawny klasztor Filipinów zbudowany w latach 1746-1777. Nieco wcześniej, na niewielkim wzniesieniu osłaniającym dzielnicę od wschodu wzniesiono kościół św. Marcina ukończony w 1685 i znajdujący się przy nim klasztor Reformatów (1693-1704).

Po lokacji Poznania w 1253 roku, na zachodnim brzegu Warty rozwinął się nowy organizm miejski, typowy dla założeń średniowiecznych: z zamkiem księcia, prostokątnym rynkiem i siatką prostopadłych ulic. Sąsiedztwo Ostrowa Tumskiego i miasta oraz mostowa przeprawa przez rzeki zapewniła osadzie rozwój. Śródka, tak jak Poznań przechodziła wszystkie kataklizmy XVII, XVIII, i XIX wieku: potop szwedzki, najazd Brandenburczyków, a potem przemarsz wojsk napoleońskich.

Początek panowania pruskiego od II rozbioru Polski w 1793 zaznaczył się stopniowym przekształcaniem miasta w fortecę. Umocnienia budowane od 1828 roku stopniowo otaczały miasto. Śródka od 1864 roku znalazła się po ich wewnętrznej stronie [3]. Gdy powstający poznański węzeł kolejowy w 1872 roku uzyskał połączenie z Bydgoszczą i Inowrocławiem, linia kolejowa została poprowadzona na nasypach i mostach na północ od Śródki.

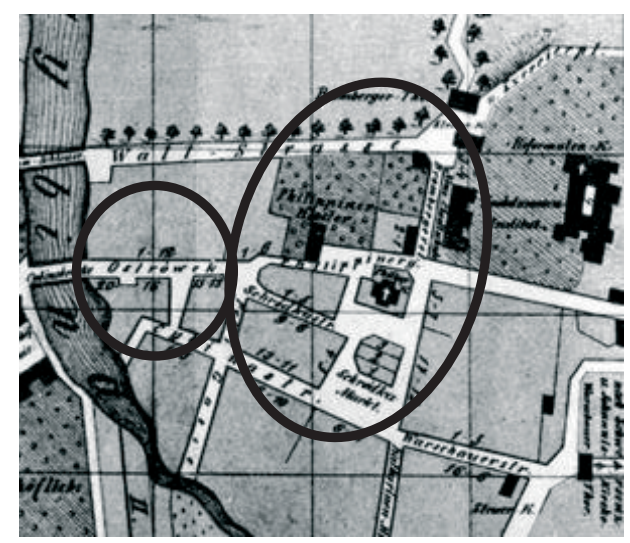

Fot. 1. Śródka w 1888 roku. Widoczny jeszcze podział na dwie osady, jest kościół, dwa klasztory, most i śluza. Mapa za: (dostęp 01.02.2016) http://poznan.wikia.com/wiki/\%C5\%9Ar\%C3\%B3dka 


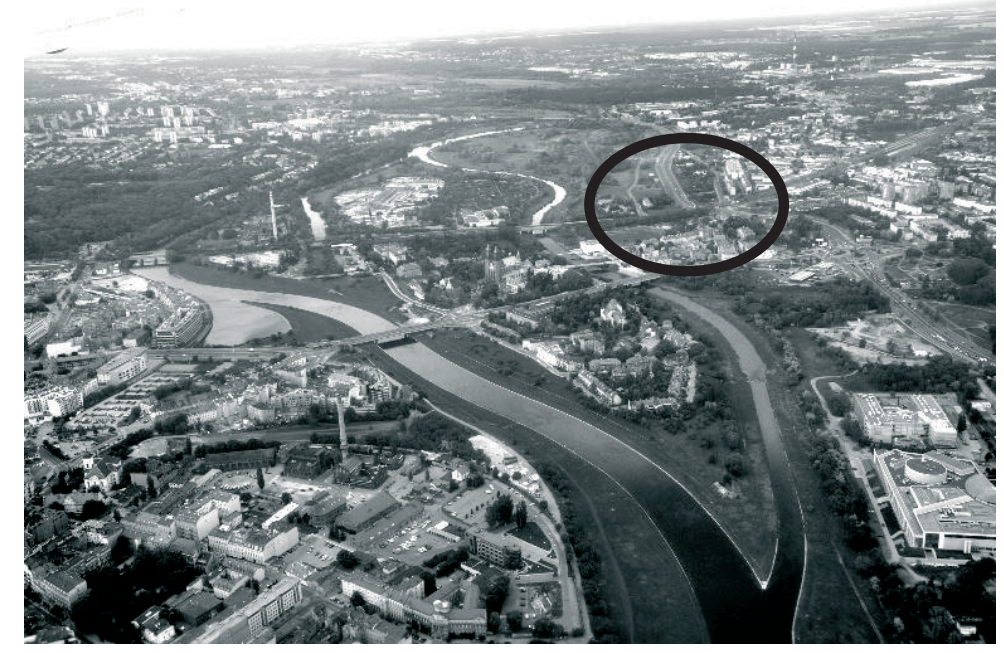

Fot. 2. Widok Ostrowa Tumskiego w widłach Warty i Cybiny, na wschód od niego leży Śródka ograniczona dwiema arteriami, rondem, linią kolejową i korytem Cybiny z odbudowanym już mostem i kładką ICHOT. Fot. aut

\section{Czas stagnacji}

Okres zaborów to początek utraty znaczenia Śródki. Zamieszkała głównie przez ludność polską stała się, tak jak i Stare Miasto, rejonem zaniedbanym. Powstająca w tym czasie nowa dzielnica, przeznaczona dla pruskich urzędników i wojskowych, oraz fortyfikacje miasta z Cytadelą, pochłonęły środki i zainteresowanie pruskiej administracji cywilnej i wojskowej. Nowa część Poznania, usytuowana na zachód od Starego Miasta spowodowała przesunięcie punktu ciężkości ku dzielnicom zachodnim i południowym.

Fortyfikacje, które od wschodu były szczególnie rozbudowane spowodowały odcięcie Śródki od będących jej naturalnym zapleczem terenów położonych na wschód, w tym najbliższej jej wsi, Główna. Mimo istnienia w fortyfikacjach Bramy Warszawskiej, wzniesionej w latach 1838-1842, otwierającej drogę na wschód, dostęp do wnętrza fortecy został bardzo utrudniony. Innym istotnym niekorzystnym zjawiskiem były powtarzające się powodzie. Ich bezpośrednią przyczyną była regulacja węzła wodnego Warty i Cybiny związana z fortyfikowaniem miasta. Budowa Śluzy Katedralnej (1833-1839), jednego z urządzeń umożliwiających zalanie niskich terenów ciągnących się ku południu doliną Cybiny i Warty, miała na celu zabezpieczenie twierdzy przed spodziewanym atakiem armii rosyjskiej od wschodu. Konstrukcja mostu ze śluzami była przeszkodą dla większych przepływów w wysokich stanach rzeki, szczególnie zimą gdy na rzece spiętrzała się kra [4].

Wskutek tych działań Śródka zaczęła przeżywać regres, większe przedsiębiorstwa przeniosły się na lepiej dostępne i bezpieczniejsze tereny w mieście. Stało się tak z pierwszą wytwórnią wódki „Wyborowej” Hartwiga Kantorowicza, która powstała na Śródce w 1823 roku i została przeniesiona w 1838 na większą, a potem na kolejną działkę w obrębie lewobrzeżnego Poznania [5]. W dzielnicy pozostały niewielkie zakłady produkujące na rynek poznański, nieduże firmy kupieckie, sklepy. Mimo to, zabudowa Śródki wzdłuż głównych ulic: Ostrówek, Bydgoskiej, Filipińskiej, to kamienice trzy-, czteroi pięciokondygnacyjne, z lokalami przeznaczonymi na handel i usługi w parterach. Świadczyło to o charakterze i statusie dzielnicy. Między tą miejską zabudową wciąż widoczne były domy parterowe, niemal wiejskie. 
Na planach miasta od 1905 aż do 1940 roku zaznaczona jest linia tramwajowa biegnąca od dworca kolejowego najpierw na Ostrów Tumski, przedłużona potem aż pod Wzgórze Reformackie na Śródce. Początkowo linię obsługiwał tramwaj konny, później elektryczny [6]. Dalej na wschód zaczynały powstawać zakłady przemysłowe skupione wzdłuż linii kolejowej, w rejonie wsi Główna.

Dwudziestolecie międzywojenne przyniosło rozbiórkę pruskich fortyfikacji (w roku 1924 rozebrano Bramę Warszawską). Na wschód, po obu stronach wylotowej ulicy Warszawskiej rozpoczęta została budowa Osiedla Warszawskiego. Ze śródeckiego Rynku od 1930 roku została poprowadzona nowa trasa trolejbusowa ulicą Warszawską aż do ul. Krańcowej [7]. Powstał węzeł komunikacyjny, korzystny dla rozwoju Śródki. Przy średniowiecznym kościele powstał „Dom Parafialny”(„Ludowy”) z salą zebrań.

W tamtym okresie główna droga wylotowa z Poznania prowadziła wciąż historycznym szlakiem: z Rynku Głównego, ulicą Wielką, Chwaliszewem, przez Ostrów Tumski, Śródkę i ulicą Warszawską, przechodząc przez dwa mosty: Chwaliszewski i Cybiński (Śródecki). Nie był jeszcze zarysowany przebieg dzisiejszej trasy północ-południe (Nowe Zawady - Jana Pawła II); komunikacja w tym kierunku, wzdłuż Warty, odbywała się niemal polnymi drogami Zawady, Podwale, i z przesunięciem, ulicą Piotrowo. Plany rozwoju Poznania w okresie międzywojennym wytyczały kierunek wschodni ekspansji, tym bardziej, że na wschód od Śródki były już rozsiane zakłady pracy. W tym czasie Śródka nadal była dzielnicą zakładów rzemieślniczych wytwarzających produkty przede wszystkim na rynek poznański, a także rejonem gdzie lokowały się warsztaty usługowe. Samych piekarni było tu ponad sześć [8]. W latach 30. XX w. na północnym krańcu dzielnicy, przed nasypem kolejowym, powstało ziemne boisko do piłki nożnej z bieżnią [9].

\section{Czas upadku Śródki}

Wskutek działań II wojny światowej w 1945 roku ogromne zniszczenia poniósł Ostrów Tumski, a także Śródka. Jeszcze w 1939 roku wysadzone zostały mosty na Warcie i Cybinie, a tymczasowe, zbudowane po wojnie, spowodowały likwidację linii tramwajowej na Ostrów Tumski, Śródkę i Osiedle Warszawskie. Zastąpiły ją trolejbusy łączące rejon Starego Rynku z przedwojenną pętlą [10]. Bezpośrednio po wojnie uzupełniono zabudowę północnej części Śródki dwoma blokami ,„patronackimi” poznańskich zakładów przemysłowych, utrzymanymi w obowiązującej wtedy konwencji socrealizmu. Sąsiadują one z boiskiem i stanowią front dzielnicy widoczny od strony linii kolejowej. Niewysokie, trzykondygnacyjne budynki o spadzistych dachach, z mansardami, gabarytami wpisały się w istniejącą zabudowę.

Podjęcie budowy drogi wylotowej z miasta w kierunku Warszawy w wersji planu z 1961 roku spowodowało przecięcie Ostrowa Tumskiego nową arterią i zajęcie pod inwestycję południowej części Śródki z rynkiem. Mimo alternatywnego rozwiązania, ten właśnie wariant został przyjęty ze względów politycznych: przecięcie w połowie Ostrowa Tumskiego: zespołu Katedry, kurii, seminarium, było celem nadrzędnym [11]. Kluczowe elementy nowej trasy: most Przemysła I i most Mieszka I, zostały oddane do użytku w 1973 roku. Powojenny, drewniany most Cybiński, usytuowany zgodnie z historycznym przebiegiem ulic został rozebrany jeszcze w latach 60. ze względu na zły stan techniczny. W ten sposób odcięte zostało tradycyjne połączenie Śródki z Ostrowem Tumskim i z lewobrzeżnym Poznaniem i przerwana oś historycznego rozwoju Poznania.

Nowa dwujezdniowa trasa, obecnie ulica Kardynała Wyszyńskiego, wyprowadziła coraz uciążliwszy miejski ruch z ciasnych ulic Śródki. W tym samym czasie, została rozbudowana prostopadła do niej ulica Podwale, radykalnie ograniczająca dzielnicę od 
wschodu, za wzgórzem Reformackim. Na skrzyżowaniu dwóch arterii, na południowo wschodnim krańcu Śródki, kosztem fragmentu dzielnicy, zostało utworzone w latach 60. $\mathrm{XX}$ w. rondo z podziemnym przejściem. Od tego momentu była to jedyna droga, jaką można było na piechotę opuścić tę zamkniętą enklawę. Na początku XXI wieku, zgodnie ze standardami, coraz ruchliwszą ulicę Podwale ogrodziły ekrany przeciwdźwiękowe, optycznie odcinając Śródkę od Ronda i terenów parku nad Maltą. Ulica Kardynała Wyszyńskiego, (kontynuacją jej jest ul. Warszawska), poprowadzona na nasypie pozwala na zaglądanie w okna nowym, ostatnio dobudowanym budynkom mieszkalnym, które są położone poniżej.

Tak dopełniło się fizyczne wydzielenie i degradacja dawnej, ważnej, historycznej części miasta.

Komunikacyjne wyłączenie z życia, pogarszający się stan upaństwowionych po wojnie budynków oraz przemiany polityczne i gospodarcze spowodowały obniżenie statusu mieszkańców i znaczenia dzielnicy. Małe firmy, warsztaty, producenci na lokalny rynek, którzy stanowili znaczny procent gospodarczego potencjału Śródki, zniknęły po reformie 1948 roku. Społeczność została zdegradowana w sensie materialnym i społecznym: kupcy i wytwórcy stali się pracownikami handlu i usług i urzędnikami [12]. O dawnym charakterze dzielnicy świadczyły jeszcze reprezentacyjne kamienice, których partery przeznaczone były na sklepy, a także pozostałości budynków „produkcyjnych” i urządzeń „technicznych” na podwórkach i w przybudówkach. Zjawisko ucieczki młodszych mieszkańców do budujących się nowych osiedli było stałym zjawiskiem od czasu, gdy zaczęto je budować w latach 60. XX w.

Okres czterdziestu lat (do otwarcia nowego/starego mostu między Ostrowem Tumskim a Śródką) był czasem wystarczającym by powojenne zniszczenia i zaniedbania obszaru Śródki usankcjonowały nieobecność dzielnicy w świadomości mieszkańców, a także władz miasta.

Jednym z jaśniejszych punktów na mapie kulturalnej miasta było istnienie małego, dwusalowego kina studyjnego „Charlie \& Marylin”, skupiającego mieszkańców, młodzież, studentów i miejskich kinomanów. Kino to mieściło się w przedwojennym śródeckim „Domu Ludowym”.

W latach powojennych dość powierzchowna modernizacja kilku budynków mieszkalnych niewiele zmieniła wygląd dzielnicy. Elementem, który nie uległ stopniowej defragmentacji, okazali się sami mieszkańcy.

\section{Czas zmian - programy ratunkowe i dzialalność Rady Osiedla}

Od połowy lat 90. XX w., na terenie dzielnicy administracyjnej Ostrów TumskiŚródka-Zawady-Komandoria, działania pro-społeczne były realizowane przez grupę mieszkańców skupioną w Radzie Osiedla. Od 1999 roku Rada wydawała kwartalnik „Wokół Śródki" a po ustanowieniu pierwszych programów integracyjnych starała się je wykorzystywać i tworzyć świadomą sytuacji lokalną społeczność. Wkrótce ilość wydarzeń kulturalnych, promujących Śródkę i skupiających mieszkańców dzielnicy i kontrastowała z jej wyglądem i stanem zabudowy.

Degradacja kamienic, problemy społeczne i świadomość rosnącej roli turystyki, zwłaszcza w obliczu nadchodzących Mistrzostw Świata w Piłce Nożnej (2012), spowodowały podjęcie przez Radę Miasta decyzji o aktywizacji miasta, w tym historycznej Śródki i Ostrowa Tumskiego. Dzielnica w 2010 roku miała niecałe 920 mieszkańców, wobec ponad 980 cztery lata wcześniej [13] i była to trwała tendencja od wielu lat.

Plan obejmował cztery długofalowe działania: 
- stworzenie w 2005 roku programu „Trakt Królewsko-Cesarski” [14], którego celem było spójne przedstawienie skomplikowanej historii Poznania od chrztu Polski poczynając

- ogłoszenie w 2007 roku Miejskiego Programu Rewitalizacji, w którym Śródka objęta została Programem Pilotażowym [14]

- otwarcie historycznego połączenia pomiędzy Śródką a Ostrowem Tumskim

- budowę Interaktywnego Centrum Historii Ostrowa Tumskiego (ICHOT), nazwanego „Bramą Poznania” i połączonego z Ostrowem Tumskim własną kładką (otwarcie planowane było na Mistrzostwa Europy w Piłce Nożnej w 2012).

Zaplanowana kolejność wydarzeń zwierała już wstępną, wewnętrzną sprzeczność: uruchomienie „Traktu” bez mostu i wyprzedzającego podniesienia jakości życia na Śródce, a także bez podstawowej atrakcji, jaką byłoby nowe Muzeum. Każda ze zmian polepszała sytuację, ale tylko synergia tych zdarzeń mogła przynieść efekty i zmienić los dzielnicy zgodnie z założeniami.

„Trakt Królewsko-Cesarski” pomyślany był jako trasa turystyczna łącząca zabytki królewskiej historii Poznania od początków Państwa Polskiego z zabytkami architektury i założeniami urbanistycznymi, jakie powstały w okresie cesarskich Prus. Śródka, sąsiednia Komandoria i Ostrów Tumski stały się jego początkowymi punktami, mówiącymi o najdalszej przeszłości. Trakt pojmowany był jako platforma dla działań miasta, mieszkańców i instytucji oraz organizacji społecznych. Miał więc także pro-społeczny charakter. W ostatecznej formie zaistniał dopiero po dwóch latach, gdy otwarto Most Cybiński - Most Biskupa Jordana. Na początku za sprawą Traktu zaczęli się pojawiać na Śródce najbardziej zdeterminowani turyści.

Ogłoszony w 2006 roku Miejski Program Rewitalizacji w pierwszych latach spowodował bardzo niekorzystne zjawiska. Naturalnym odruchem właścicieli kamienic i lokali (w tym również miasta) wobec tak dobrej perspektywy, było podniesienie czynszów [16]. Brak osłony, stosowanej zazwyczaj w takich przypadkach dla mieszkańców i najemców lokali [17] spowodował zamknięcie niewielu istniejących sklepów i wyprowadzenie się najlepiej rokujących właścicieli i najemców: mieszkańców „z dziada-pradziada”, pracowników nauki, młodych przedsiębiorców i artystów [18]. Nie udźwignęła podwyżki czynszu podniesionego przez miasto kawiarnia-księgarnia [19]. Przez kilka lat Śródka wydawała się zupełnie pozbawiona perspektyw. W tym samym czasie zniknęło również z mapy kulturalnej kino studyjne, przejęte wraz z zabudowaniami po klasztorze Filipinów przez Kurię. W miejscu ośrodka zdrowia (klasztor) i kina (Dom Parafialny/Ludowy) powstała przykatedralna szkoła muzyczna I stopnia i gimnazjum. Budynki zostały wyremontowane, podświetlone, teren uporządkowany, ale nie ulega wątpliwości że siła przyciągania ludzi przez nową placówkę jest mniejsza. Impuls do zmian na lepsze miało przynieść dopiero otwarcie Mostu Biskupa Jordana.

Historia umieszczenia XIX wiecznego przęsła mostu w nowym miejscu wiąże się z aktywnością Rady Mieszkańców Osiedla [20]. Jej usiłowania doprowadziły do „szczęśliwego" finału. W planach miasta rozważane były dwa warianty nowego mostu. Pierwszy zakładał budowę nowej lekkiej kładki pieszej, według drugiego do budowy nowej przeprawy miano wykorzystać istniejące łukowe, nitowane przęsło rozebranego kilka lat cześniej mostu św. Rocha. Konstrukcją, kształtem i wielkością odpowiadało ono potrzebom odnawianej przeprawy. Dzięki zabiegom Rady Osiedla został przyjęty drugi wariant, choć przetransportowanie przęsła na nowe przyczółki wiązało się z dużymi trudnościami [21]. Ocalona zabytkowa konstrukcja przypominała zniszczony w czasie wojny most Cybiński. Przejście jest obecnie przeznaczone dla ruchu pieszego i rowerowego. 


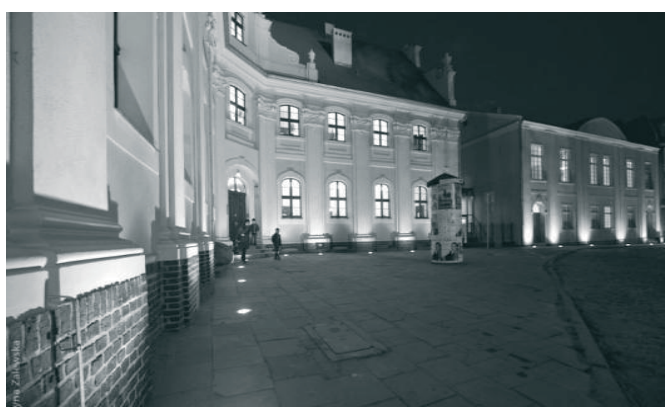

Fot. 3. Katedralna Szkoła Muzyczna w dawnym klasztorze Filipinów i Domu Ludowym. Fot. aut

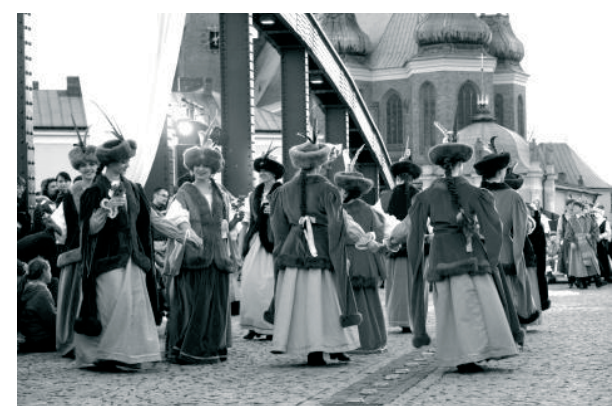

Fot. 4. Cykliczne wydarzenia kulturalne na moście Biskupa Jordana Fot. aut

W ramach programów unijnych zbudowane zostało (2015) Interaktywne Centrum Ostrowa Tumskiego (ICHOT), muzeum, które przedstawia rozwój najstarszych fragmentów Poznania. Umieszczone na śródeckim brzegu Cybiny, z Ostrowem łączy się pieszą kładką umieszczoną w miejscu dawnego mostu i Śluzy Katedralnej. Surowa, niemal sześcienna betonowa bryła muzeum jest na ukos „pęknięta” kadrując widok na katedrę. Konkurs na muzeum, ogłoszony w 2009 roku, wygrała pracownia AD ARTIS Emerla, Jagiełłowicz, Wojda, z Krakowa.

W ślad za opisanymi inwestycjami i zmianami, na głównej ulicy pojawiły się nowe lokale gastronomiczne i sklepy. W 2015 roku został oddany do użytku Hotel Śródka. Jest to adaptacja dwóch sąsiednich kamienic z lat 1906 - 1908, tworzących pierzeję naprzeciw kościoła św. Małgorzaty. Obok mieszkań kamienice mieściły lokale usługowe i handlowe. Częściowo zniszczone w czasie wojny zostały odbudowane. Ich gruntowna przebudowa przywróciła centrum dzielnicy budynek o skromnym secesyjnym wystroju i potrzebnej funkcji. „Powróciła” restauracja, która niegdyś znajdowała się w parterze kamienicy narożnej. [22].

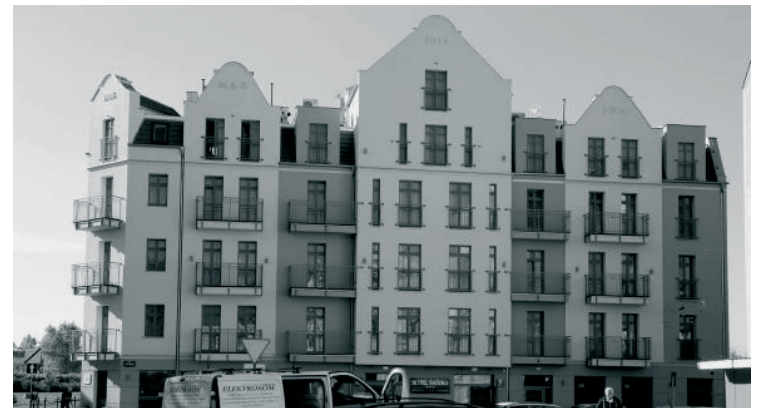

Fot. 5. Hotel Śródka 2015. Fot. aut

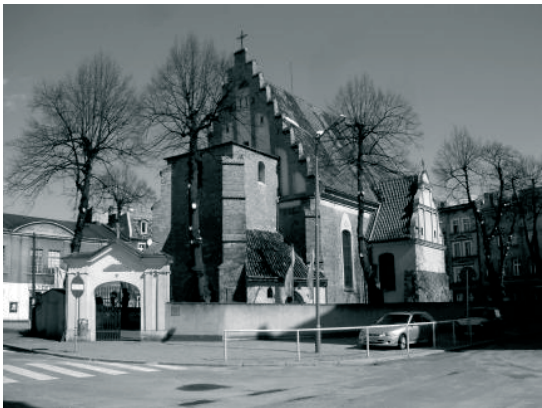

Fot. 6. Kościół św. Małgorzaty. Fot. aut

Działalność Rady Osiedla, która stara się osobność, wydzielenie Śródki przekuć w jej atut była i jest bardzo intensywna. Organizowane już od lat 90. XX w. imprezy integrujące mieszkańców otrzymały wsparcie programu rewitalizacji i dotacji pro-społecznych umożliwiających organizację imprez o szerszym niż dotąd zasięgu. Most Biskupa Jordana od 2007 roku stał się centrum tych działań. Cyklicznymi wydarzeniami są m.in. Śródeckie Spotkania (VIII edycja w 2015 roku), Targi Średniowieczne (VI edycja), Koncerty Śródeckie w kościele św. Małgorzaty, cykl imprez „A w niedzielę po sumie na moście”, Dzień Sąsiada, Przechadzki po Śródce. Dużą rolę odgrywa Ośrodek Szkolno-Wychowawczy dla 
Dzieci Niesłyszących, placówka mieszcząca się w budynkach po klasztorze Reformatów. Młodzież uczestniczy aktywnie w wydarzeniach dając przedstawienia i popisy, towarzysząc zapraszanym artystom, aktorom, muzykom.

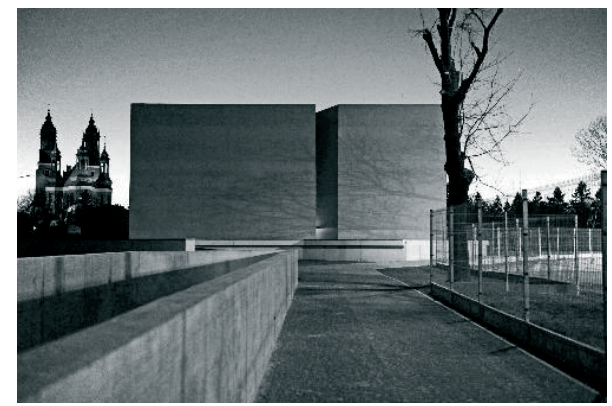

Fot. 7. Brama Poznania ICHOT, 2015. Fot. aut

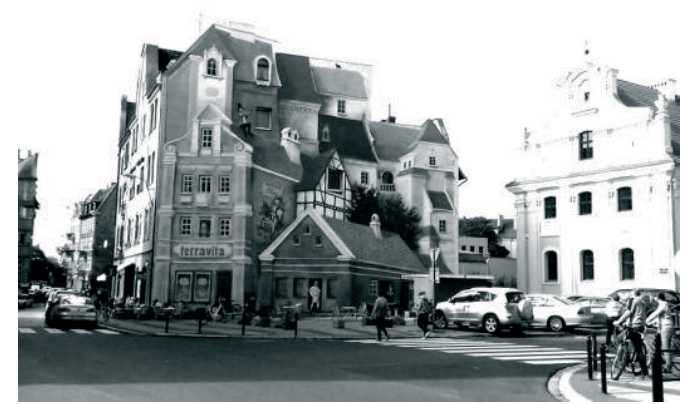

Fot. 8. Mural na ślepej ścianie kamienicy. Fot. aut

Od 2015 roku przestrzeń otwartych tarasów przed ICHOT jest również miejscem wydarzeń kulturalnych dzielnicy. Udział mieszkańców jest coraz większy i coraz większa ich liczba uczestniczy w cyklicznych i jednorazowych wydarzeniach. Współpraca Rady z organizacjami i fundacjami oraz grupami artystów, miała na celu zarówno integrację mieszkańców jaki upiększenie dzielnicy. Spektakularną zmianą okazało się wykonanie (2015 rok) muralu doskonale wpisującego się w przestrzeń przedkościelnego placu. Umieszczona na ślepej ścianie kamienicy wychodzącej na plac kompozycja „uzupełnia” istniejącą zabudowę. Mural "Opowieść śródecka z trębaczem na dachu i z kotem w tle", autorstwa Radosława Barka, w bajkowej konwencji przedstawia spiętrzone kamienice, budynki ze sklepami i ludzi w sytuacjach, jakie mogłyby się wydarzyć w tym miejscu.

\section{Podsumowanie}

Przebieg procesu rewitalizacji na Śródce wykazuje, że:

- przy podejmowaniu rewitalizacji istotne jest przewidywanie zachowań społecznych i korzystanie $\mathrm{z}$ doświadczeń miast, które podobne akcje przeprowadziły

- kolejność podejmowania i kończenia działań rewitalizacyjnych nie jest obojętna dla finalnego jej efektu a także przebiegu pośrednich etapów rewitalizacji

- długoterminowe działania pro-społeczne, integrujące mieszkańców są podstawową formą zapewniającą zmianę postaw i akceptację dla zmian u ludzi obojętnych i negatywnie nastawionych

- ważne jest aby proces gentryfikacji, zachodzący na obszarze Śródki i nieodłącznie towarzyszący rewitalizacji przestrzeni miejskich został zatrzymany na pewnym, optymalnym dla dzielnicy poziomie [23].

\section{Literatura}

1. Karolczak Z. Najstarsze dzieje Śródki. Kwartalnik „Wokół Śródki”. (ed. Rada Osiedla Ostrów Tumski-Śródka-Zawady-Komandoria), nr 3(26) 2006, Wydawnictwo Kontekst, Poznań, 2006.

2. Lubierska-Lewandowska J. Kilka słów o poznańskich nekropoliach. wtg-gniazdo.org/upload/opracowania/poznańskie_nekropolie.pdf (dostęp 01.03.2016).

3. Biesiadka J. i inni. Twierdza Poznań. Wydawnictwo Rawelin, Poznań 2006, s. 26-27.

4. Biesiadka J. i inni. ibidem, s. 263-264. 
5. Bardzińska-Bonenberg T. Poznan 19th century postindustrial areas and buildings in the city centre. Technical Transactions. Architecture. 2(2A) (2014) 45.

6. http://www.mpk.poznan.pl/o-mpk/historia.

7. Cofta Sz. Trolejbusowe sentymenty. Kwartalnik „Wokół Śródki”. (ed. Rada Osiedla Ostrów Tumski-Śródka-Zawady-Komandoria), nr 3-4, Protext Sp., Poznań 2000.

8. Cofta A. Śródecka piekarnia Leona Cofty. Kwartalnik „Wokół Śródki”. (ed. Rada Osiedla Ostrów Tumski-Śródka-Zawady-Komandoria), nr 1(54), Wydawnictwo Kontekst, Poznań 2014.

9. Ksiąszkiewicz J. Moje miejsce do biegania: stary-nowy stadion na Śródce, za: http://bieganie.pl/?show=1\&cat=50\&id=543 (dostęp 10.03.2016).

10. Cofta Sz., op.cit

11. Kodym-Kozaczko G. Rozwój Poznania w planowaniu urbanistycznym w latach 1900-1990. Architektura i urbanistyka Poznania w XX wieku, (red. T. Jakimowicz), Wydawnictwo Miejskie, Poznań 2005, s.62, 65.

12. Powalisz-Bardońska M. Ludzie i domy. Kwartalnik „Wokół Śródki”. (ed. Rada Osiedla Ostrów Tumski-Śródka-Zawady-Komandoria), nr 4 (14), Wydawnictwo Kontekst, Poznań, 2004.

13. Sprawozdanie Oddziału Rewitalizacji Biura Koordynacji Projektów Urzędu Miejskiego w Poznaniu, 2010.

14. Matyaszczyk D. Poznań, Trakt Królewsko-Cesarski, przewodnik turystyczny. Wydawnictwo Miejskie, Poznań 2007.

15. Uchwała Rady Miasta nr LXXXIX/1006/IV/2006, z dnia 7 marca, Poznań 2006.

16. Ciesiółka P. Gentryfikacja jako efekt rewitalizacji. Przykład Poznania. Portal internetowy www.urbanistyka info, ISSN 2081-1322, Poznań 2010.

17. Bardzińska-Bonenberg T. Tendencje ksztaltowania zabudowy śródmiejskiej w procesie rewitalizacji. Wydawnictwo Politechniki Poznańskiej, Poznań 2008, s. 99.

18. Bardzińska-Bonenberg T. Sondaż wśród studentów WAPP. 2010, w zasobach archiwum ZHAiU PP.

19. Łukaszewski J. Wywiad z właścicielem księgarni-kawiarni na Śródce. Gazeta WyborczaPoznań, 19.05.2011.

20. Kwartalnik „Wokół Śródki”. (ed. Rada Osiedla Ostrów Tumski-Śródka-Zawady-Komandoria), nr 3 (18) 2004 i kolejne do 2007, Wydawnictwo Kontekst, Poznań.

21. Ryżyński A. Przenoszenie mostu nad mostem. Czasopismo Techniczne. Budownictwo 9(2-B) (2009).

22. Klause G. Historia przeksztatceń miejsca. Kwartalnik „Wokół Śródki”, (ed. Rada Osiedla Ostrów Tumski-Śródka-Zawady-Komandoria) nr 1, 2, 3, Wydawnictwo Kontekst, 2015.

23. Bardzińska-Bonenberg T. On gentrification of historical districts in Poznan. Technical Transactions. Architecture 1(1A) (2012) 43-52.

\title{
Śródka District in Poznan - physical and mental borders within the city
}

\author{
Teresa Bardzińska-Bonenberg \\ Faculty of Architecture and Design, University of Arts in Poznan, \\ e-mail: teresa@bardzinska-bonenberg.pl
}

\begin{abstract}
Poznań was established. Access to water and the main route from the east to the west let it become a stable trade and manufacturing centre. Under Prussian rule the floods which followed were a result of construction of the Prussian fortress. The district became less attractive. The interwar period brought some changes for
\end{abstract}


the better. The Second World War operations, demolition of the bridge and of the tramway line was followed by a new double lane road built on the Śródka Market Square area and have separated the district from the city. In 2006 Śródka became a part of the Urban Redevelopment Program. Rental fees immediately went up, as a result of which most shops and few remaining eating places were closed and the most prospective residents moved out. However, the subsequent programs turned out to be successful: the Royal-Imperial Route has attracted tourists while the Gate of Poznan Museum and a large mural referring to the history and the atmosphere of the old Sródka have changed the image of the district. They have been followed by new eating places, shops and a hotel. The Śródka District Council has been cooperating with architects and artists to integrate residents and make the citizens of Poznan accustomed to the "new", interesting, historical district of the city. The purpose of the report is to present the activities of the local community which influences the decisions made by the city authorities. It was possible to change the course of events because there has existed an objecting group putting forward reasonable ideas and implementing them.

Keywords: decisions, development, degradation, contradiction, community, administration. 